УДК 327

Alexey GROMYKO

\title{
MULTI-DRIFTING AND NOT YET LOST OPPORTUNITIES
}

Abstract. The Euro-Atlantic region is characterized by growing divergence between different actors. Russia - West political relations are in deep freeze. The factor of Donald Trump and new populism both in the USA and Europe change profoundly the tenets of liberal international order, which until recently was taken for granted by the West political establishment. Business as usual will not been restored in the interaction between the two sides of the Atlantic. This may be lamented but this new reality can also be used to promote long term interests of all players. The author suggests the steps that can be taken in order to minimize the sharp tensions of the transition period and maximize opportunities to escape the dangerous zone of confrontation.

Key words: multi-drifting, routinization, new normality, Intermediate Range Nuclear Forces Treaty, START 3, Russia, Euro-Atlantic, multipolarity, polycentricity, multilateralism.

Originally, the Euro-Atlantic region was a place, which post-Soviet Russia saw as its final destination, a kind of an extended/enlarged West- the West plus Russia. Many remember that we used to call it a space from Vancouver to Vladivostok. Then after Yugoslavia and Iraq it was replaced by a narrative of Greater Europe from Lisbon to Vladivostok. By 2018 we had ended up with the schism between Russia and the West as well as with multiple splits and cracks in the EuroAtlantic itself.

New significant changes came with the phenomenon of Donald Trump. They have enhanced tensions not only between the USA and Europe but also inside Europe. Today the European Union is more divided than ever since 1957. It has also failed to prevent the nightmare coming true of loosing a member which unsurprisingly turned out to be Britain. Nevertheless, the question is not if the project is going to survive but if the EU will be able to regroup and to contribute to the shaping of a new equilibrium in international relations.

Wherever we look now, we diagnose growing divergence: between Europe and the USA, between the USA and Russia, between the EU and Russia, between the USA and China. We witness multi-drifting or multi-divergence at a time when centrifugal forces tear up the fabric of international relations. But there are some exceptions, among which there are a strong one and a moderate one: the former is the strategic convergence between Russia and China, which for the foreseeable future serves national interests of both countries and the latter one are integration processes in Eurasia and broader in the Asia-Pacific region.

Instead of being Eurocentric or Western-centric the world is getting more and more Asiacentric and this is not going to change for a long time. Accordingly, the USA under B. Obama declared its Pivot to Asia and later Moscow followed with its Turn to the East. Conceptually, instead of the extended West or Greater Europe narratives, these days in Russia we develop discourse of

\footnotetext{
(C) Alexey Gromyko -Doctor of Sciences (Politics), Corresponding Member, Professor of Russian Academy of Sciences, Director of the Institute of Europe, Russian Academy of Sciences. Address: 11-3, Mokhovaya str., Moscow, Russia, 125009. E-mail: alexey@gromyko.ru.

DOI: DOI: http://dx.doi.org/10.15211/vestnikieran6201846
} 
Greater Eurasia: post-Soviet space integration projects plus their partners in the Asia-Pacific region, primarily One Belt, One Road and ASEAN+. If previously the idea of «integration of integrations» in Russia meant first of all interaction between the EU and Russia-led post-Soviet integration, nowadays it implies interaction first of all between the Eurasian Economic Union (EEU) and the AsiaPacific region.

But it is advisable to keep in mind that while knowledgeable people deliberate on America First or Global Britain or the EU Global strategy or Russia's intentions, there is one more megaproject, which is called Greater Asia with China at its core. And its advent also needs a system of checks and balances to preserve the equilibrium - this famous Graal of international relations. A fair balance by default in international relations is impossible if asymmetries become too pronounced. Benign hegemony is an illusion and the whole history of humanity underlines this point.

The situation around and in Europe is getting worse not better. Partly it resembles the interwar years: we live in the aftermath of the world economic crisis, nationalism and protectionism are on the rise, the European security system is in shambles, there are isolationist tendencies in the US. There is not much left of the American Dream as it was known until recently since the 1930's and neither of the European Dream, which inspired so many people in the EU just 15 years ago. Nowadays billions of people are inspired by the Chinese Dream, which has become a part of the official lexicon in Beijing.

It seems that multipolarity is moving along the track of crystallizing regional orders, which are at odds with each other. This is not a co-operative polycentrism, based on multilateralism and common rules enshrined in the Charter of the United Nations and in the Helsinki process. There is a silver lining in the cloud as Russia and a number of European countries try together to salvage the nuclear deal with Iran, object to exterritorial sanctions of the USA, criticize Washington for a decision to abandon the Intermediate Range Nuclear Forces Treaty (INF Treaty) and move the US embassy from Tel Aviv to Jerusalem. Russia and a number of European states are also engaged in Normandy format, talk with each other on conflict resolution in Syria and build Nord Stream 2. By doing so they show that co-operative polycentrism with the EU and Russia as stakeholders is possible. However, in order to bring this about some basic issues should be sorted out including legitimate security interests of the parties and the problem of sanctions.

Europe and different parts of Europe need long term geopolitical leverage. Without a tangible degree of pan-European consolidation the European Union, Russia and other regions and states inbetween will suffer. New Normality in the relationship between Russia and the West is a dangerous delusion. What we do have in is reality is routinization of abnormal situation, which cannot last for long. It will either find its solution in return to strategic co-operation between Russia and the EU or both parts of the Continent will not achieve their long term political, social and economic goals.

Recommendations:

1. Resumption of talks on the revamped Basic Treaty, this time in a form of negotiations between the European Union and the Eurasian Economic Union.

2. Resumption of talks between the EU and Russia on the visa free regime.

3. Joint actions in the Normandy format in order to facilitate the discussions on the new hybrid UN-OSCE peacekeeping mission in Donbas.

4. Common EU-Russia efforts with Washington and vis-a-vis Washington to minimize damage, ensuing from its decision to leave the INF Treaty.

5. To launch Strategic Stability consultations between Russia and the United States (Russian proposals on this subject was handed over by Vladimir Putin to Donald Trump in Helsinki in July 2018; they include the INF and START 3 issues). It is quite amusing to observe these days how, 
toeing the line of Washington, some politicians and specialists in Europe justify the US decision to leave the INF Treaty by reference to alleged violations of the treaty by Russia. As if Russia for years has not been pointing out to violations of the treaty by the USA or has not been calling for military specialists of the two countries to meet to discuss all the issues involved. This problem, accusations and counter accusations should be dealt with in a professional way, not through megaphone diplomacy.

6. To resume some least sensitive channels of interaction in the NATO-Russia Council, for example the work of the NRC Science for Peace and Security Committee.

7. To maintain momentum of the November Russia-Turkey-Germany-France summit on Syria.

DOI: DOI: http://dx.doi.org/10.15211/vestnikieran6201846 